proportion of patients if valid, durable results are to be obtained.

We are indebted to Professor J J McNeil for advice on statistics.

1 Furlan AJ, Whisnant JP, Elveback LR. The decreasing incidence of primary intracerebral hemorrhage: a population study. Ann Neurol 1979;5:367-73.

2 Garraway WM, Whisnant JP, Drury I. The continuing decline in the incidence of stroke. Mayo Clin Proc 1983;58:520-3.
3 Steiner I, Gomori JM, Melamed E. The prognostic value of the CT scan in conservatively treated patients with intracerebral hematoma. Stroke 1984;15: 279-82.

4 Garde A, Bohmer G, Selden B, Neiman J. 100 cases of spontaneous intracerebral haematoma. Diagnosis, treatment and prognosis. Eur Neurol 1983;22:161-72.

5 Helweg-Larsen S, Sommer W, Strange P, Lester J, Boysen G. Prognosis for patients treated conservatively for spontaneous intracerebral hematomas. Stroke 1984;15:1045-8.

(Accepted 19 fuly 1988)

\title{
Filter paper sampling of blood infected with HIV: effect of heat on antibody activity and viral infectivity
}

\author{
B Evengard, M von Sydow, A Ehrnst, \\ P O Pehrson, P Lundbergh, E Linder
}

\section{Department of \\ Parasitology, National \\ Bacteriological \\ Laboratory, S-105 21 \\ Stockholm, Sweden \\ B Evengard, $M D$, registrar in \\ infectious diseases \\ E Linder, MD, assistant \\ professor}

\section{Virology Department,} Central Microbiology Laboratory of Stockholm County Council,

Stockholm, Sweden

$M$ von Sydow, MD, clinical

virologist

A Ehrnst, MD, associate

professor

Department of Infectious

Diseases, Karolinska

Institute, Roslagstull

Hospital, Stockholm,

Sweden

P O Pehrson, MD, internist

$\mathrm{P}$ Lundbergh, $\mathrm{MD}$, associate

professor

Correspondence to:

Dr Linder.
The filter paper technique for blood sampling has not gained wide acceptance, mainly owing to incomplete standardisation. It has several advantages over venepuncture: it is less distressing for patients; samples are more easily transported; and the risk of accidental transmission of infectious agents through broken glassware and needles, etc, is reduced. We have standardised the technique: ${ }^{1}$ Antibodies to human immunodeficiency virus (HIV) and HIV antigens have been detected in extracts of dried blood on filter papers. ${ }^{23}$ We assessed the effect of heating filter paper samples on antibody activity and infectivity of HIV.

\section{Patients, methods, and results}

We obtained venous serum samples and capillary blood collected on filter papers from 19 people attending an outpatient department for patients infected with HIV at Roslagstull Hospital for Infectious Diseases, Stockholm, and from one healthy laboratory worker The blood samples on filter papers were dried at room temperature overnight and then either left at room temperature or heated at $56^{\circ} \mathrm{C}$ for one or 18 hours. A disc of $6.2 \mathrm{~mm}$ diameter was punched out of the filter paper and extracted in $0.5 \mathrm{ml}$ phosphate saline buffer with $0.05 \%$ polysorbate 20 (Tween 20 ) for two hours at room temperature. ${ }^{1}$ Serum samples were diluted 1:100 and eluates of filter paper discs used undiluted. HIV antibody activity was measured with an enzyme linked immunosorbent assay (ELISA) (Vironostika antiHTLV-III micro-ELISA, Organon Teknika, Boxtel, Holland) and western blotting performed with antigen strips (Biotech, Rockville, Maryland).

HIV infectivity was measured by using HIV obtained from freshly infected HUT-78 cells when the culture had become antigen positive in an antigen capture enzyme immunoassay (Abbott Laboratories,

Mean ${ }^{\star}$ optical density of culture supernatants of human mononuclear cells incubated with extracts from filter discs impregnated with HIV from freshly infected HUT-78 cells that were extracted in RPMIT medium immediately, after drying at room temperature for one hour, or after heating at $56^{\circ} \mathrm{C}$ for one hour. Values for discs heated at $56^{\circ} \mathrm{C}$ for one hour were all zero

\begin{tabular}{lccccccccc}
\hline & \multicolumn{8}{c}{ Days of culture } \\
\cline { 2 - 10 } Treatment of discs & $5-8$ & $9-12$ & $13-16$ & $17-20$ & $21-24$ & $25-28$ & $29-32$ & $33-36$ & $37-40$ \\
\hline $\begin{array}{l}\text { Immediate extraction } \\
\begin{array}{l}\text { Dried at room } \\
\text { temperature before } \\
\text { extraction }\end{array}\end{array}$ & 0.171 & 0.207 & 0.405 & 0.427 & 1.115 & $>2.000$ & $>2.000$ & $>2.000$ & $>2.000$ \\
& 0.134 & 0.091 & 0 & 0 & 0 & 0 & 0 & 0
\end{tabular}

* Of two values.

†Roswell Park Memorial Institute.
North Chicago, Illinois). Discs of filter paper were soaked with $25 \mu \mathrm{l}$ of the supernatant containing HIV and extracted in duplicate in $0.5 \mathrm{ml}$ of the medium produced by Roswell Park Memorial Institute supplemented with $10 \%$ fetal calf serum. Samples were extracted immediately or after drying at room temperature or heating at $56^{\circ} \mathrm{C}$ for one hour. Each filter paper extract was then added to roughly $20 \times 10^{6}$ mononuclear cells from human peripheral blood stimulated with phytohaemagglutinin, and the supernatants were assayed for HIV antigens twice weekly for six weeks. A culture was regarded as positive when the supernatant showed a rise in absorbance value on two successive occasions. Declining absorbance values were regarded as indicating a lack of replication of HIV.

Ten patients had antibodies against HIV whereas nine patients and the healthy laboratory worker did not. Activity of the antibody in the filter paper extracts was found to be equal to that shown by the diluted serum samples. The western blots obtained with filter paper extracts and serum were indistinguishable.

Heat treatment of filter papers for one hour at $56^{\circ} \mathrm{C}$ did not alter the optical density of extracts. Incubation for 18 hours at $56^{\circ} \mathrm{C}$ reduced the antibody reactivity, but in all seropositive samples it was still high. Extracts from discs soaked with supernatants from the culture containing HIV gave rising or continuously high optical densities in the assay for HIV antigens, indicating the existence of replicating virus (table). When the filter paper discs were left to dry at room temperature or heated at $56^{\circ} \mathrm{C}$ for one hour before extraction no replication was found.

\section{Comment}

HIV antibodies in filter paper extracts resisted heating at $56^{\circ} \mathrm{C}$ for one hour, whereas no replicating virus could be shown when the filter paper was left to dry at room temperature or heated at $56^{\circ} \mathrm{C}$ for one hour. Martin et al reported that HIV diluted in human serum was inactivated when heated at $56^{\circ} \mathrm{C}$ for 10 minutes. ${ }^{4}$ Resnick et al, however, reported that only after five hours at $56^{\circ} \mathrm{C}$ was the virus no longer detectable. ${ }^{5}$ Our results show that heating capillary blood on filter paper for one hour at $56^{\circ} \mathrm{C}$ efficiently inactivates HIV but not HIV antibody. More exact evaluation of this is in progress.

We thank Ms Eva Stenehall, Ms Johanna Sigte, and Ms Gun Sundin for technical help and Dr Marianne Forsgren, Professor Örjan Strannergård, and Professor Olavi Mäkälä for reviewing the manuscript.

I Evengård B, Lundbergh P, Linder E. Standardization of a filter paper technique for blood sampling. Ann Trop Med Parasitol 1988;82:295.

Farzadegan $\mathrm{H}$, Quinn $\mathrm{T}$, Polk BF. Detecting antibodies to human immunodeficiency virus in dried blood on filter papers. I Infect Dis 1987;155:1073-4.

3 Nielsen C, Bygbjerg IC, Vestergaard BF. Detection of HIV antigens in eluate from whole blood collected on filter paper. Lancet 1987;i:566-7.

4 Martin LS, Mcdougal JS, Loskoskki SL. Disinfection and inactivation of the human $\mathrm{T}$ lymphotropic virus type IIU/lymphadenopathy-associated virus. I Infect Dis 1985;152:400-3.

5 Resnick L, Veren K, Salahuddin SZ, Tondreau S, Markham PD. Stability and inactivation of HTLV-III/LAV under clinical and laboratory environments. IAMA 1986;255:1887-91.

(Accepted 23 May 1988) 